\title{
Las cartas de Santa Rosa
}

\author{
Rosa Carrasco \\ Universidad Femenina del Sagrado Corazón
}

Las cartas de Rosa de Santa María que se han hallado hasta ahora son tres. Una fue dirigida a fray Jerónimo Bautista (I) y se encuentra en el monasterio de Santa Catalina. De las otras dos, guardadas en el monasterio de Santa Rosa, la primera estuvo dirigida a un religioso llamado Bartolomé de Alcalá (II). La última fue para la señora María de Usátegui (III). ${ }^{1}$

La caligrafía de las cartas I y II es bastante pareja: presenta caracteres sueltos, aspecto que las diferencia de la generalidad de cartas escritas por mujeres en los siglos XVI y XVII. Con pocas excepciones, aquellas misivas femeninas muestran más bien rasgos vacilantes en los que se nota falta de pericia, indicio de la escasa formación cultural de la que generalmente adolecían las mujeres y, fundamentalmente, la falta de práctica de escritura, de acuerdo a la costumbre de la época.

En cuanto a la autenticidad, si se compara la caligrafía de La escala mística y las cartas, se encuentran semejanzas con I y II, no así con III. Aquí se observan diferencias en los trazos, de donde se puede colegir que III parece transcripción de algún original. Como prueba que corrobora esta conjetura aducimos que existen dos copias: una en el Santuario de Santa Rosa (que fue casa de Santa Rosa) y otra en el monasterio de Santa Rosa (que fue casa de doña María de Usátegui y don Gonzalo de la Massa). Ambas son consideradas originales, pero lo que deja un margen de inseguridad es que, pese a que estos dos textos presentan los mismos trazos de escritura, es poco probable que RSM las haya escrito por duplicado, dada la privacidad que deseaba mantener sobre su persona, y porque, además, se trata de cartas de agradecimiento cuyo contenido no era especialmente importante dentro de la correspondencia.

Nos interesa poner de relieve en este trabajo las formas de cortesía empleadas por Rosa de Santa María y su conformidad con fórmulas de la época, pero también con el contenido expresado en el mensaje y la personalidad

\footnotetext{
${ }^{1}$ Aclaramos que esta numeración en romanos tiene simplemente valor identificatorio para su estudio. Para más referencias y en relación a otros testimonios de la santa remitimos a nuestro estudio: Santa Rosa de Lima. Escritos de la santa limeña. Lima, Facultad de Teología Pontificia y Civil de Lima, 2017. En la transcripción respetamos la ortografía original.
} 
excepcional de esta mujer patrona de América, la misma que en sus cartas se expresaba con un espíritu humilde y sencillo. El estilo de su escritura manifiesta la fuerza de su personalidad como una de las grandes mujeres de su época.

\section{El cuidado de las formas}

La temática discursiva presenta una secuencia organizada, un desarrollo coherente y una construcción lingüística clara. Este carácter coincide con una observación que hizo don Gonzalo de la Massa sobre el cuidado que Rosa tenía en la precisión de su manifestación verbal, a fin de que sus palabras transmitiesen contenidos que respondieran a su intención y no se prestasen a ambigüedades:

Era tan pura en su hablar que si deçia alguna cosa a que [se] pudiesse dar más que un sentido decia esto digo o quiero decir. (AAL. Proceso. Gonzalo de la Massa 1630: 401)

Sabemos que antes de generarse la comunicación, la palabra se presenta como una virtualidad, pero una vez concreta en el mensaje, el receptor se apropia del contenido; y este proceso puede dar pie a diversas interpretaciones, ya que si bien es cierto existe un código compartido, cada enunciación puede generar contenidos de connotaciones particulares ${ }^{2}$.

En cuanto al tipo de lenguaje, las cartas de RSM presentan un código usual, excepto en la carta I, donde frases como "lengua de ángel... había yo de tener" y: A. "apresure el paso porque ya no es tiempo padre mío de cernir, mas antes es ya tiempo de aMassar con muy grande priesa" B. "porque las almas ambrientas de Christo no perezcan", proverbio que alude al vocabulario práctico pero elevado. Figura con carácter metafórico en la que se quiebran las formas simples del lenguaje denotativo.

El estilo en las tres cartas es directo, excepto en el argumento tercero de la carta I. Aquí emplea un estilo indirecto, ya que reproduce un enunciado: "Nuestro provincial dice que si viene la licencia para que estemos sujetas a la orden, que lo ha de contradecir".

\section{El trato a los destinatarios}

Las cartas I y II están dirigidas a religiosos y en el trato a cada uno de ellos se perciben diferencias: I "mi padre" y II "padre de mi alma". ¿Significa esto que el segundo religioso fue confesor de Rosa, no así el primero? A diferencia de los

\footnotetext{
${ }^{2}$ El código literario se propone la polivalencia, sobre todo en el medioevo. Se tiende a que la palabra presente varios contenidos; a más connotaciones se atribuye más riqueza poética, por lo que se tiende a interconectar sentidos. El ideal de la riqueza semántica es opuesto al ideal del texto pragmático; se apoya en las relaciones de equivalencia que están contenidas en los paradigmas del código.
} 
dos anteriores, la destinataria de III es una mujer laica y Santa Rosa hacia ella emplea una construcción con dos vocativos que marcan solidaria y tácitamente la diferencia entre la maternidad espiritual y la biológica: "Madre de mi alma y señora mía". En todas las cartas ella otorga a los receptores un estatuto de superioridad ante el cual aparece sumisa.

Para tratar al destinatario reverencial las tres usan gramaticalmente las formas pronominales y verbales correspondientes al usted (vuestra merced), de tercera persona, formas ya difundidas en Castilla desde el Renacimiento. ${ }^{3}$

Los vocativos que emplea RSM en las dos cartas a los religiosos eran usuales en la época; aparecen en la correspondencia de otras religiosas a sus prelados, con algunas diferencias. Cuando el trato no era muy formal, se empleaban expresiones de mayor proximidad, como "Ylustrisimo reverendisimo señor. A mi venerable padre" (MDSJ. 1669, leg. I, exp. 1, [s.n.]). En otras misivas, el lenguaje era más distante: "El Espiritu Santo excelentísimo señor sea con su alma de vuestra excelencia" (AAL III:11) como escribe Arcángela Micaela, religiosa del monasterio del Prado. Otras frases semejantes eran: "Mi señor", "Ilustrísimo señor". A diferencia de este tratamiento reverencial, los vocativos que empleaban las religiosas en la correspondencia familiar podían ser algo más efusivos, Micaela de Iporri, monja de La Encarnación, en una carta a su hermano escribe: “Hermano mío de mis ojos" (AAL. Micaela Iporri, I:48). Este último tipo de fórmulas no fueron empleadas por RSM, hasta donde permite inducir nuestro limitado corpus.

Las fórmulas retóricas de sumisión se hacen patentes en la despedida de las cartas de RSM. Cada una presenta variables expresiones de modestia: "Humilde esclava de Jesús mi esposo y sierva de vuestra paternidad" (carta I), "Humilde hija de vuestra paternidad" (carta II) y "Esclava de la Virgen María y sierva de vuestra paternidad" (carta III). Estas estrategias discursivas eran usuales en los monasterios de monjas dentro de misivas que podían estar dirigidas a laicos o religiosos: Arcángela Micaela, religiosa del monasterio El Prado, solicitando un pago de treinta y cinco pesos en carta a un "soldado de caballo" del once de junio de 1679 emplea una frase semejante a las de RSM: "Su minima su[b]dita y cierba [i. e. sierva] de vuestra excelencia" (AAL. Arcangela Micaela, 1679, III:11). En la correspondencia a los prelados las fórmulas podían ser: "mi padre y señor cuyas manos besa su mas umilde sudbdita" (AAL. doña Mayor de Quijano religiosa de

\footnotetext{
${ }^{3}$ La novedad del usted pasó inicialmente a las capitales de corte en las Indias. Por la época del nacimiento de Santa Rosa, la moda en Lima era el usted (de "vuestra merced") en el lenguaje reverencial y el vos y el tú en el no reverencial. El antiguo vos reverencial del estrato social superior había cambiado y era tratamiento para el inferior o para iguales cuando no había familiaridad, en boca de un noble indicaba falta de respeto. Para el igual se usaba desde el Renacimiento la tercera persona. El usted (vuestra merced) se empleaba entre personas iguales de condición hidalga o en el trato del inferior al superior. En la corte de Felipe II se registra un altercado porque un funcionario trató a otro con el antiguo referencial vos, ya entonces solo empleado como signo de superioridad del destinatario.
} 
la Encarnación III:39) "“De vuestra excelencia mi señor su mas umilde subdita que muda [sic] corason le ama" (AAL. II:2]), como escribe Ana de San Joseph, religiosa del monasterio del Carmen, el 21 de julio de 1679; o bien "Mi señor en Dios y en mi conciencia" (AAL. III: 39) como escribe Francisca de Córdova, religiosa del monasterio de la Encarnación. Las religiosas empleaban también construcciones más formales cuando en sus cartas a los prelados: "confiada a la merced que vuestra me ase a quien ama(?) nuestro señor" (AAL. Jacoba de Larrinaga Salazar III:39 1631: leg. 3, [s.n.]), "nuestro Señor guarde a vuestra merced muchos años y oy sabado” (AAL. María de Santillán: III:39)

En la despedida de las misivas I y III, RSM repite la misma fórmula de sumisión "sierva de vuestra paternidad" que hace patente una actitud de obediencia a cada uno de los receptores. En la primera carta, esa frase constituye una expresión que se ciñe más a las fórmulas retóricas perlocutivas, pues hay un interés para que el receptor cumpla los encargos que se le habían puntualmente encomendado. Este anhelo de cumplimiento lo manifiesta el emisor de manera explícita insistiendo con el mismo verbo en presente y en futuro: "tengo... [y] tendré hasta que Dios sea servido cumplírmelos". En la tercera carta esa misma frase responde menos al deseo de formalidad, pues reitera un compromiso de obediencia manifiesto en el cuerpo de esa carta ["la divina majestad va servida de comunicarme su divino espíritu para que acierte hacer lo que vuestra merced manda que yo de mi parte haré todo lo que en mí fuere"']. Este matiz permite señalar que aquí la despedida responde más bien a una voluntad de "abajamiento", ya que desde un punto de vista psicológico entraña modestia personal. En contraste con la actitud de obediencia (cartas I y III), la despedida de la carta II insiste en recordar la condición de padre = guía espiritual (confesor) de fray Bartolomé de Alcalá.

\section{Fórmulas y recursos retóricos}

El empleo de las fórmulas de devoción y las fórmulas de humildad ${ }^{4}$ como recursos retóricos se relacionan. En las cartas I y III los sintagmas: "Humilde esclava de Jesús" y "esclava de la Virgen María", respectivamente, son formas lingüísticas socializadas, pero deben interpretarse de acuerdo con la intención del emisor. El contenido religioso formaba parte del vocabulario cotidiano de RSM; era una característica frecuente de su manifestación oral:

\footnotetext{
${ }^{4}$ El tópico de la "falsa modestia" se podía combinar con las fórmulas de sumisión cortesana. Este tratamiento procedía de los antiguos modelos medievales cristianos que a su vez se basaban en modelos paganos romanos. En esas fórmulas una persona se confesaba inferior a otra por respeto o reverencia. Pero esos contenidos son diferentes de las fórmulas de devoción de la humildad cristiana, donde frases como "Mi Señor", que se refieren a Dios, son auténticas expresiones de reverencia.
} 
sus conversaciones eran de cosas de Dios con muy grande regocixo y alegría (AAL. Proceso. María de Bustamante 1630: 317)

En las cartas se combinan continuamente alusiones religiosas. Este lenguaje, además de ser una característica de la expresión verbal y epistolar de RSM, resulta más insistente que el inventario empleado en la correspondencia de otras religiosas. En la carta I: "nuestro Señor" (tres veces), "glorificado sea el nombre de Jesucristo crucificado", "Sumo Bien", "mi Señor", "Dios", “Christo", "nuestro Redentor", "Misericordia de Dios", "divina Magestad" (tres veces), "humilde esclava de Jesús, mi esposo"; y refiriéndose a Santa Magdalena: "imagen gloriosa de Santa María Magdalena", "Santa gloriosa". Una expresión excelsa "lengua de ángel", parecería hiperbólica si no recordáramos sus raíces escriturísticas (Cor.13-1). En la carta II menciona la: "santísima Trinidad que santifique el espíritu de vuestra paternidad y a mí me dé su gracia"; también "el Espíritu Santo llene a vuestra paternidad"; en otras frases alude a Jesucristo: "Divina Magestad" (dos veces), "gloria de Dios", "por amor de Dios", "mi Dios", "por amor del mismo Jesucristo", "guarde nuestro Señor". "mi Señor Jesuchristo"; también se refiere a la Virgen: "Virgen madre de Dios Reina de los ángeles y Señora nuestra, la cual Señora", "Madre de Dios", "digna madre de Dios"; finalmente, menciona a santos: "glorioso y bienaventurado San Bartolomé", "glorioso San Barlolomé", "glorioso santo", "San Agustín", "Santo Domingo", "San Francisco". En la carta III: "Jesucristo sea glorificado", "la divina magestad", "su divino espíritu”, "Dios oiga mis pobres oraciones", "nuestro Señor pague... con premio de gloria, "nuestro Señor me guarde a V.M.", "esclava de la Virgen María".

En la tercera carta, el sintagma "Jesús sea glorificado" abre la comunicación en la carta de RSM. Frases semejantes empleaban algunas monjas en cartas dirigidas a religiosos y laicos, "El Espíritu Santo" (AAL. Arcángela Micaela 1679: 2, s/n) escribía Arcángela Micaela, religiosa del monasterio del Prado, el once de junio de 1679 y "Jesús, María y Joseph" (AAL. Ana de San Joseph 1679: 2, s/n), Ana de San Joseph del monasterio el Carmen en una carta a un religioso. Un término más usual era "Jesús". También se hallan sintagmas como "Jesús sea con vuestra ilustrísima", según escribía la abadesa del monasterio de Descalzas de San José, en 1637, a un prelado, (AAL. Beatriz de la Ascención 1637: 1.2, s/n) en esta última frase se establecía una relación entre la divinidad y el receptor. ${ }^{5}$

Respecto del marco referencial que se construye en el discurso, la carta I, aunque tiene por finalidad última la espiritualidad, su contenido discurre fundamentalmente a través de contextos objetivos de la realidad. En cambio, el tenor de la carta II se centra fundamentalmente en el ámbito espiritual y la carta III conjuga lo real y espiritual. Su implicación con la divinidad, la vida espiritual y la realidad material permiten a RSM cierta aproximación hacia los receptores y

\footnotetext{
${ }^{5}$ El tema de las cartas de mujeres en los siglos XVI y XVII en el Perú lo he estudiado y el texto está en revisión para ser editado.
}

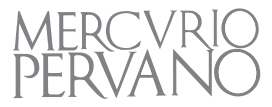


hacia los requerimientos que suscita el empleo de la escritura, presupuestos que le permiten seleccionar las estrategias discursivas adecuadas para cada misiva.

\section{La carta I}

El manuscrito original de la carta se encuentra físicamente enmarcada en un cuadro, pero deteriorada y algo arrugada: la parte inferior del papel está rota y le falta un fragmento. Detrás del cuadro se ha pegado un recorte de periódico con el contenido completo de la carta, sin indicarse la fuente bibliográfica de esa transcripción impresa. Por esta razón, reproducimos con letra cursiva esa última sección, la que corresponde a la fuente periodística. ${ }^{6}$ La presentamos en transcripción paleográfica:

A mi padre fray Geronimo Bautista guarde nuestro Señor en España o donde estuviere.

Glorificado sea el Santisimo nombre de Jesuchristo crucificado y el mismo sumo bien sea en el alma de Vuestra paternidad.

Lengua de angel, Padre mio abia yo de tener [para] poder referir las cingulares mercedes que mi Señor sin yo mereser a cido cerbido de acerme acerca de los muchos deseos que de la fundacion del monasterio de mi madre Catalina de Sena, yo tengo y tendre asta que Dios sea serbido de cumplirmelos y pues no la tengo quiero callar, y solo pedir a V.P. apresure el paso porque ya no es tiempo Padre mio de cernir, mas antes es ya tiempo de aMassar con muy grande priesa por que las almas ambrientas de Christo no perescan.

En otras dos e escrito a V.P. dando cuenta del citio y renta que para el dicho Monasterio ay las contradiciones son muchas y [roto] estas solo son de nuestros prelados, esto digo para que con todo haya prevencion, de suerte que aqua [sic] no se nos ponga algun impedimento.

Para ayuda de las costas enbio a vuestra paternidad cien ducados de a onse reales, cada uno llebalos el padre presentado Obando de la Compañia de Jesus. Mi Padre Fray Gonsalo Garcia, enbia a vuestra paternidad una memoria y pues es causa propia por Nuestro Señor le pido padre Mio, procure cunplimiento della.

Advierta vuestra paternidad que las monjas emos de estar sujetas al ordinario, por dos rasones, la primera porque entiendo que se serbira mejor a Nuestro Señor y la segunda porque Nuestro Padre Probincial dise que si biene la licencia para que estemos sugetas a la orden, que lo a de contradecir en lo demas bea vuestra Paternidad lo que mas conbiene que en todo me remito a memoria de mi padre como e dicho las cartas y los recaudos bengan encaminadas al contador de la crusada Gonzalo de la Massa, que con mucha voluntad desea faborecer esta causa y por orden suya ban estos cien ducados.

\footnotetext{
6 La separación espaciada, entre las partes del cuerpo de la carta, corresponde a nuestra segmentación analítica.
} 
Por que se que mi padre escribe largo en esta no lo sere sino en solo pedir a vuestra paternidad que por la sangre de Nuestro Redentor Jesucristo [roto] me encomiende a la dibina Magestad y lo propio piden mis hermanas que ellas y yo lo asemos con particular cuidado, que por la Misericordia de Dios son ya cuatro las que traen el Abito, de mi madre Santa Catalina de Sena, cuya imagen pido me traiga de Sevilla y va encomendad [sic] a un mercader que ahora va alla que se dice Juan Fernandez Pereira; lleva con que pagar la echura y lleva la orden de que la haga el maestro que hizo la Imagen Gloriosa de Santa Maria Magdalena de nuestra casa. Pido a vuestra paternidad pida a la Divina Magestad la traiga con bien a la Santa Gloriosa, pida nos sea favorable en nuestra prestension.

Mi señora Doña Isabel Mejia, besa a vuestra paternidad la mano, y lo mismo hacen mis padres que este bendito sea mi Dios, todo con salud, y yo tambien la tengo. La Divina Magestad sea loada, la cual Divina Magestad, que a vuestra paternidad y lo conserve en su santo ser[v]icio. De esta ciudad y de mayo cinco de este año de seiscientos y trece.

Humilde esclava de Jesus mi esposo y cierba de vuestra paternidad

Rosa de Santa Maria ${ }^{7}$

Firmado

\section{Análisis de la carta I}

A través de la mención del nombre del receptor ${ }^{8}$-fray Jerónimo Bautista- ${ }^{9}$ se personaliza y se declara un destinatario explícito del mensaje y se asegura una relación unívoca. Este religioso dominico había viajado del Perú a Europa ("en España o donde estuviere"). Pese a ello, el remitente no pone en duda la recepción de la carta. Supone que fray Jerónimo se encuentra en una situación itinerante y realizará varias escalas.

\footnotetext{
7 MSR. Carta original de Rosa de Santa María a fray Bartolomé, cuadro con marco de plata.

8 El nombre se omitía en algunas cartas. Gran parte de la correspondencia que enviaban las religiosas a sus prelados consignaba fórmulas genéricas. La perspicuitas tiene lugar cuando el hablante menciona nombres propios y el oyente tiene la seguridad de la relación unívoca de la representación (Henrich LAusBerg: Elementos de retórica literaria. Madrid, Gredos, 1975, pp. 77-78). El nombre propio Jerónimo y el apellido Bautista designan exclusivamente a la persona. Podría haber confusión si RSM hubiera escrito solo el nombre.

${ }_{9}^{9}$ Diecisiete años después de la fecha de la escritura de la carta de RSM, fray Jerónimo Bautista sería el procurador en la causa de "las prueuas de la vida y milagros de la Bendita Rosa de Santa María" (Proceso, 1630, p. 4). Una carta de este religioso se encuentra en el Proceso que se levantó en Lima para la beatificación de RSM, en la cual solicitaba el 9 de marzo de 1630 al arzobispo de Lima, la traducción del latín de las "letras apostólicas remisoriales y compulsoriales" que se habían enviado desde Roma para dar inicio a la declaración de los testigos y a la presentación de pruebas.
}

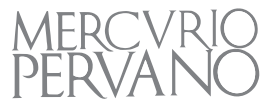


Algunas marcas verbales reflejan en forma explícita e implícita la posición que ocupa el emisor en relación con el receptor; unas corresponden a la investidura del destinatario y otras al trato que le concede la remitente. Los mismos criterios se aplican en II. Las razones del tratamiento gramaticalmente otorgado son: 1. La dignidad sacerdotal dentro del contexto religioso, que implica una gradación superior frente a la feligresía. 2. Esa jerarquía se modula en el apelativo "padre" (tanto en I como en II). El término entraña estatus, autoridad protectora y capacidad de influir en el remitente. 3. El posesivo "mi" (en I, II y III), añade cierta nota afectiva.

A través del contenido de la carta se emplean algunos tropos que sustituyen el cuerpo léxico de la univocidad por expresiones próximas: "padre mío" (tres veces), "vuestra paternidad" (ocho veces). Algunas variantes del tratamiento sustituyen al nombre propio, como se forman a base de un nombre común, pueden aplicarse a otro referente. La forma "mi padre" es empleada también para referirse a fray Gonzalo García. ${ }^{10}$

\section{La invocación}

Esta parte se inicia con frases de exaltación a Dios y con una invocación a que proteja a fray Jerónimo Bautista. Se emplea una antonomasia o tropo impropio: "Sumo bien", donde el nombre común sustituye al nombre propio. ${ }^{11}$

Tanto el destinatario-vocativo como la invocación y el argumento final reiteran el mismo contenido: Dios proteja al destinatario. Expresa el deseo de una protección física y espiritual; la invocación insiste en el aspecto espiritual, y finalmente alude a la investidura religiosa del beneficiario. ${ }^{12}$

El modo verbal que corresponde a esta sección del texto, es el subjuntivo optativo, que expresa los deseos del hablante respecto de la esfera espiritual, la que caracteriza el entorno dentro del cual se sitúan receptor y emisor ("guarde", "estuviere", "sea"). El verbo "guarde" invoca una protección espiritual y física; la representación corporal queda más precisa en el sintagma "donde estuviere"; aquí el adverbio y el verbo denotan una ubicación espacial de alguien. La locución "sea en el alma" ("el mismo sumo bien") expresa el anhelo de presencia y permanencia de la divinidad en el alma de fray Jerónimo; en la religión católica las condiciones para este estar con Dios son tres: mantener la pureza espiritual, no pecar y orar.

\footnotetext{
${ }^{10}$ Michel le Guern considera este tipo de expresiones metáforas del lenguaje religioso que se emparentan con la lítole.

${ }^{11}$ Fontanier clasificó este tipo de figura de expresión como "sinécdoque de individuo" (véase Bice Montara Garavelli, Manual de retórica, Madrid, Cátedra, 1991, p. 198).

${ }^{12}$ Las peticiones reiteradas a la protección divina eran usuales en la correspondencia familiar de sociedades católicas como la peruana y española durante el siglo XVII.
} 
El cuerpo de la carta lo hemos dividido en cinco argumentos. El primero se ofrece según un esquema que podríamos resumir en explicación [justificación], persuasión (invocación) [justificación].

El hipérbaton que modifica la construcción sintáctica contribuye a imprimir un tono exclamativo en la frase inicial: "Lengua de ángel había yo de tener para referir las singulares mercedes". El cambio temático respecto al inicio de la carta subraya la fuerza emotiva del juicio.

El enunciado empieza con una alusión bíblica: "lengua de ángel",13 y con el juego de contrastes: "pues no la tengo quiero callar", establece la posición del yo en función de una autoevaluación comparativa. Como resultado se destaca la diferencia entre las cualidades humanas y angelicales. Esta "contradicción" marca la diferencia entre una condición necesaria y su carencia. Recurso verbal que tiene un efecto psicológico, pues al proponerse el yo inexperto e incapaz, apela al tópico de la modestia, ${ }^{14}$ que induce al receptor a inclinarse hacia el emisor por una respuesta natural que predispone a ser benevolente con el que se encuentra en dificultades. ${ }^{15}$ Sin embargo, la sugerencia tiene una fuerza ilocucionaria mayor, ya que entramos en el discurso de lo no dicho, que da lugar a una superlativización elocuente del contenido que se omite, pues destaca en forma suma la excelencia de los favores divinos por la incapacidad de referirlos.

Desde las primeras palabras, todo el discurso de la carta gira alrededor de un eje: las extraordinarias gracias de Dios en los pasos para la concreción del objetivo, que es la fundación del monasterio de Santa Catalina.

En el enunciado: “apresure el paso porque (causal) ya no es tiempo padre mío de cernir, mas antes es ya tiempo de aMassar $^{16}$ con muy grande priesa / $\underline{B}$.

\footnotetext{
13 Esta idea se encuentra en la carta de San Pablo a los Corintios: "Si yo hablara todas las lenguas de los hombres y de los ángeles, y me faltara amor no sería más que bronce que resuena y campana que toca" (1 Co 13. 1), para marcar la diferencia entre la manifestación humana y la excelsa de los ángeles. ¿La frase de RSM se basó en esta cita o fue una creación propia? La metáfora emplea un tropo por salto a través de una comparación entre conceptos no sinónimos, en consonancia con la técnica del barroco (ver H. LAUSBERG, Elementos..., p. 96). ${ }_{14}$ Aunque la retórica antigua recomendaba al orador que se presentara con modestia ante sus oyentes, esa captatio benevolentiae era una estrategia de persuasión, que no debe confundirse con la humildad, virtud fundamental del cristiano, ajena a cualquier receta persuasiva aplicable a objetivos humanos (política-foro). Lo que era receta para actuar sobre el oyente, para el creyente es reconocimiento del orden real ("humildad es andar en verdad", según Santa Teresa de Jesús).

${ }^{15}$ Sobre la tópica de la "falsa modestia", véase Ernest Robert CuRTIus, Literatura europea y Edad Media latina. Méjico, Fondo de Cultura Económica, 1955, pp. 127-131.

16 La idea de adecuación de los tiempos para las diversas actividades se encuentra muy claramente en el Eclesiastés: "Hay un tiempo para cada cosa, y un momento para hacerla bajo
}

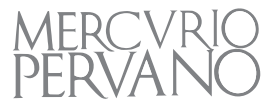


Por que las almas ambrientas de Christo no perezcan". El lenguaje simbólico en A apela a la necesidad de actuar con prontitud. Este requerimiento crea una sensación de movimiento ("apresure el paso", "con muy grande priesa") con una serie de expresiones propias del ámbito culinario ("cernir", "aMassar"), circunscrito tradicionalmente a las mujeres y en los monasterios de mujeres y hombres, a las hermanas legas y hermanos legos, a pesar de que el llamado con premura a la actividad no es ni mujer ni lego, sino un religioso.

La primera construcción se enlaza con la conectiva causal en $\underline{B}$, que reitera la dimensión que inquieta al yo: el "tiempo". Esta idea se encuentra presente en la subordinada final "las almas hambrientas de Christo no perezcan", que establece una semejanza entre lo temporal y entre la existencia biológica y la vocación espiritual. El emisor sitúa la comparación en el plano empírico de la experiencia, aunque el contenido corresponde al plano espiritual; metafóricamente se alude también al efecto que la fundación del monasterio de Santa Catalina significaría en el desarrollo de la vida espiritual de las religiosas.

Se establece la dependencia y contraposición entre $\mathrm{A}$, que conecta enunciados que se sitúan en un plano concreto del hacer, y $\underline{B}$, que expresa la finalidad y el objetivo que apremia el cumplimiento de $\underline{\mathrm{A}}$ : que las vocaciones para la vida religiosa no se pierdan. Esta razón se convierte en el eje central que, en síntesis, sería la necesidad de que se funde el monasterio de Santa Catalina a fin de que las religiosas se dediquen a la oración por la redención.

Las dos imágenes se construyen con un vocabulario concreto, a la manera de las parábolas del Nuevo Testamento, utilizan imágenes realistas para ilustrar una idea abstracta. Constituyen alegorías en las que se sustituye una idea por su relación de semejanza con otra y se llega a la similitud. ${ }^{17}$ Simultáneamente sugieren una relación de orden y organización en la ejecución de las tareas por realizar.

De esta manera, en la secuencia de pasos que el receptor está desarrollando, se presuponen tres momentos: 1. inicial y de preparación: cernir; 2. intermedio de realización: aMassar; y 3. [final de logro: hornear]. Aunque se mencionan únicamente los dos primeros, queda sobreentendido y presupuesto que falta el tercero. $^{18}$

El objetivo de esta sección es persuadir con recursos verbales. Al sentido contribuyen estos presupuestos implícitos: 1. un credo común; 2. un interés compartido; 3. la intención de expansión de las órdenes religiosas con la fundación de nuevas casas.

el cielo: Hay tiempo de nacer y tiempo de morir; tiempo para plantar, tiempo para arrancar lo plantado." (Ecl 3, 1-2).

17 Ver H. LAusberg, Elementos..., pp. 212-213.

18 Estos enunciados no desentonan con el contexto, ya que aparecen con naturalidad. Para los tratadistas la figura parece óptima cuando no lo parece (Cfr. Longino, De lo sublime, Buenos Aires, Aguilar, 1972, p. 97). 
El estilo intensificatorio del barroco, propio de la época, no deja de estar visible en estos textos. Estilísticamente se nota en esta carta una inclinación bastante barroca al énfasis y a la hipérbole. En el empleo de recursos lingüísticos, destacamos por ejemplo la propensión enfática que sobrepasa los parámetros normales: "singulares mercedes", "muchos deseos", "grande prisa", "almas hambrientas".

El juego verbal entreteje el plano humano y el plano divino. El emisor supone que cuenta con el apoyo de la divinidad y también con el de un grupo de personas (laicos y religiosos) ${ }^{19}$. De esta confluencia depende finalmente la concreción de la fundación: de lo humano que planifica y ejecuta acciones específicas y de lo divino, que corresponde a la voluntad que las inspira y permite.

El esquema secuencial del segundo argumento es: a. explicación; b. justificación. El primer enunciado alude de manera tácita a dos cartas anteriores en las que se enviaron noticias sobre el lugar donde se ubicaría el monasterio y sobre los fondos para realizarla. No se desarrollan estos puntos, ya que son parte de una comunicación anterior. A pesar de que no hay ninguna mención explícita a respuestas, la remitente presupone que fray Jerónimo Bautista es una persona de absoluta confianza y, en consecuencia, ella puede contar con su apoyo en la ejecución de los trámites o encargos que se le deleguen.

Se puede inferir que la permanencia de fray Jerónimo en Europa fue larga, pues con la presente serían tres cartas que se le habían enviado. Sin embargo, no se puede establecer el tiempo que media entre cada misiva, aunque sí se puede recordar que cada viaje del Perú a España, significaba un trayecto que se cubría en meses.

La ejecución del objetivo central, que es la fundación del monasterio, concierta dos realidades en las que se obra simultáneamente: 1) en Lima hay avances concretos: el haber conseguido el terreno y los fondos y renta para sostenerla, datos que se complementan con otros de distinta naturaleza: el envío

\footnotetext{
${ }^{19}$ El religioso Antonio de Vega Loayza de la Compañía de Jesús, Ministro y Juez Comisario de la Santa Inquisición, testificó el 11 de diciembre de 1617. Declaró que RSM deseaba fundar el monasterio de Santa Catalina de Siena y que "para este fin buscó e intentó diferentes medios y trazas las cuales comunicó varias y diversas veces con este testigo y le dijo que para este efecto había buscado de limosnas y despachado a Europa por medio de padres de Santo Domingo y con uno de ellos trescientos o cuatrocientos pesos, que no se acuerda puntualmente este testigo la cantidad de plata para una imagen de la Gloriosa Santa para el dicho monasterio y para ciertas licencias y otros recaudos los cuales estuvo esperando hasta a lo último de su muerte y pidió varias veces a este testigo la ayudara para la dicha fundación..." (MSR. Antonio de Vega Loayza 1630, p. 179). Añade que muchas personas contribuyeron con donaciones.
}

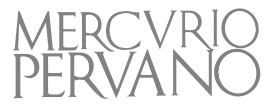


de dinero ("cien ducados de a once reales" ${ }^{20}$ ) y de una "memoria" 21 (además, hay un informe nuevo sobre la cantidad de doncellas dispuestas a ingresar como religiosas: "son ya cuatro las que traen el hábito"22); 2) en Europa ("en España o donde estuviere"), fray Jerónimo Bautista era el responsable de la ejecución de los trámites y de encargos adicionales, como el de traer a Lima la estatua de Santa Catalina de Siena.

El conocimiento de tendencias adversas a la obra fundacional que se propone RSM ["las contradicciones son muchas"] la lleva a señalar de manera sutil ["para que en todo haya prevención"] las providencias necesarias para contrarrestarlas. Ante todo, mantener la reserva o, tal vez, el secreto sobre las actividades y los trámites. Además, tener cautela en la elección de las personas (eventualmente los prelados) a quienes se acudiría, para evitar impedimentos tanto en España como en Roma. Este cuidado se debía a que, por una parte, podría entorpecerse el desarrollo de las actividades o, de la otra, retardarse o impedirse el objetivo, puesto que las personas a quienes se debía acudir serían, generalmente, aquellas que tenían capacidad de decisión e influencia y estuviesen de acuerdo con la fundación. Además, era muy probable que quienes en el Perú no aceptaban esa fundación ya hubieran comunicado sus razones a España y Roma, o las comunicarían en los informes que se les solicitara.

Era muy probable que quienes se oponían a la fundación hubiesen justificado su posición con diversos alegatos como eran los problemas económicos de algunos monasterios, aunque podían aducirse otras causas. Alrededor de esa época, en Lima existía un clima adverso a la fundación de otros monasterios de mujeres. No era caso único, fue problema que también tuvieron que superar en Europa Santa Teresa de Jesús (1515-1582), en España; y Mary Ward (1585-1645) en Inglaterra y en los países donde se proyectó su obra. ${ }^{23}$

\footnotetext{
${ }^{20}$ El dinero fue una donación del Contador don Gonzalo de la Massa. Este tipo de aportes databa de una concesión que realizó el Papa después de la batalla de Lepanto en 1581 por haber hecho retroceder a los turcos. Se liberó de días de ayuno y abstinencia al año como premio, pero en retribución los fieles debían contribuir con limosnas a Roma para obras de bien.

${ }^{21}$ Ha de entenderse el término como una lista o relación de actividades a realizarse, ya que el objetivo que interesa es que cumpla lo estipulado en dicha lista.

22 El ejemplo de RSM llevó a que otras jóvenes de Lima siguieran sus pasos: si en 1613 se menciona a cuatro, en 1617 se menciona además a otras ocho doncellas. ¿Eran algunas las mismas que en 1613? Una Navidad, las ocho doncellas (Luisa de Santa María, Catalina, Francisca, que después ingresaron en el monasterio de Santa Catalina, Felipa de Montoya, Bartola López y Ana de los Reyes, María de Jesús, Leonor de Victoria y al parecer también se les unió María Antonia) prepararon en casa de RSM velos, palmas y guirnaldas de flores y se dirigieron a la Iglesia de Rosario en Lima donde después de comulgar recibieron el hábito.

23 En efecto, esta actividad se inscribe dentro de una orientación llevada a efecto por otras mujeres, la inglesa Mary Ward en Inglaterra, Italia, Alemania; y Teresa de Jesús en España, quienes a partir de carismas diferentes fundaron nuevas casas. Alfredo López AMAT, Mary Ward. Madrid, Biblioteca de Autores Españoles, 1990 y TeresA DE Jesús Vida. Burgos, Monte Carmelo, 1984.
} 
El lenguaje en esta sección es conciso y rápido; manifiesta lo esencial sin digresiones. Los verbos se encuentran en modo indicativo como acciones con existencia objetiva, excepto dos verbos en subjuntivo que expresan posibilidad ("con todo haya prevención", "no se nos ponga algún impedimento).

El esquema del tercer argumento es complejo y se podría dividir en dos: explicación - persuasión (invocación). Se mencionan como puntos concretos tres aspectos: 1) el monto del dinero para cubrir los gastos; 2) la memoria o relación de trámites que debe realizar; 3) la instancia para su ejecución.

A diferencia de la alusión común a "nuestros prelados"24, en que se omiten nombres propios, en esta, tal vez por la importancia y lo reciente del envío, se nominaliza. Se menciona al padre Obando, quien lleva el dinero y posiblemente también la "memoria", aunque no se especifica. Todas estas menciones no hacen sino reiterar el interés por la fundación del monasterio ${ }^{25}$ y la continuidad de la comunicación para acudir desde el Perú con lo necesario.

Los términos de esta sección son sencillos y no requieren de mayor comentario; sin embargo, obran presupuestos pragmáticos en relación a la "memoria". Es un documento que posiblemente había sido redactado por fray Gonzalo García, religioso dominico que apoyaba en forma incondicional la fundación ("pues es causa propia"). En ese documento se habría precisado la secuencia de pasos a seguir para los trámites y actividades por realizarse, lo que revelaba un conocimiento directo sobre el particular.

Las palabras clave "cumplimiento-cumplir" relacionan las dos acepciones del mismo lexema "realización, perfección" // "otorgamiento, concesión", aspectos que se mencionaron antes: las acciones humanas y divinas. Se encuentran en el Argumento-I: "procure cumplimiento [realización] della" y en el Argumento-III “Dios sea servido cumplírmelos [conceder]". En ambos sintagmas el emisor es consciente de que el resultado depende de voluntades ajenas. ¿Se puede

\footnotetext{
Se pueden establecer diferencias entre las fundaciones que proyecta Rosa de Santa María y Santa Teresa de Jesús. 1. RSM inicia los trámites para la fundación de una casa sin ser religiosa de la orden y STJ trabaja sobre una congregación ya establecida; 2. RSM se encuentra en el Perú y los trámites demoran por la distancia no solo a España sino también a Roma. STJ puede realizar su obra con mayor facilidad pues se encuentra en la península; 3. RSM sabía que se iba a fundar el monasterio de Santa Catalina que se regiría por la Regla de esos monasterios; STJ luchó para fundar monasterios sin rentas y logró su cometido y pudo realizar su reforma pese a las adversidades.

Monasterios femeninos de Lima -la Encarnación (1561), La Concepción (1573), la Santísima Trinidad (1579), Concepcionistas Descalzas de San José (1603), Santa Clara (1606)- tenían grandes problemas económicos por su administración ineficiente y poblacionales por la cantidad y heterogeneidad de personas que vivían en el claustro (religiosas de velo negro, de velo blanco, novicias, donadas, sirvientas, señoras de piso, doncellas y niños), por lo cual se tenía prevenciones y era necesario cumplir numerosos requisitos para fundar nuevas casas.

${ }^{24}$ Eran los superiores de una orden, no necesariamente sacerdotes.

${ }^{25}$ RSM tenía la seguridad absoluta de que se fundaría el monasterio e incluso diseñó en una tableta de cera el plano del edificio.
}

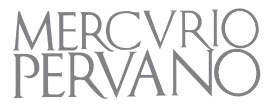


afirmar que esta polisemia ejerce una influencia que obliga inconscientemente a fray Jerónimo Bautista? La persuasión y la invocación se fusionan directamente dentro de un tono invocativo: "padre mio procure el cumplimiento della" que para lograr mayor eficacia acude a una motivación religiosa que obliga a un creyente y, en mayor medida, a un religioso (es causa a favor del Señor): "por nuestro Señor". En el argumento IV repite la misma estrategia de solicitar un favor a fray Bautista: "por la sangre de Nuestro Redentor".

En coherencia con el plano objetivo del actuar, los juicios son asertorios, afirman simplemente la realidad. Los verbos se encuentran en presente del modo indicativo y, por tanto, el contenido está considerado en su existencia objetiva, sin marcas temporales excepto el último subjuntivo ("procure") que alude a esta objetivización, ya que se articula dentro de una retórica persuasiva.

Este tercer argumento se continúa con otro esquema: explicación [justificación] - explicación (apelación) - explicación [justificación]. La vida comunitaria en los monasterios de religiosas podía depender del ordinario ${ }^{26}$ o de los prelados de una orden. RSM se inclina por la primera opción debido a que el provincial de los dominicos no aceptaba que su orden asumiese esa responsabilidad ${ }^{27}$, a pesar de que el monasterio se creaba bajo la advocación de Santa Catalina de Siena, que fue terciaria dominica y a pesar de que en Lima no existía ningún convento dominico en la rama femenina ${ }^{28}$. RSM justifica la opción de sujetar la fundación al ordinario con una razón irrebatible en el contexto religioso: "servir mejor a Nuestro Señor". Esta afirmación constituye la tesis de toda la carta y el fundamento de todos los afanes de la Santa.

RSM señala con claridad cada detalle al cual se refiere, puesto que la distancia no da la posibilidad de conseguir aclaraciones inmediatas. Otro de los objetivos de la información de RSM; además de los puntos manifiestos, radica en su deseo de contribuir de esa manera a que se agilicen los trámites. Dentro de este contexto, su postulado "en lo demás vea vuestra paternidad lo que más conviene que en todo me remito a la memoria de mi padre" revela confianza en el buen criterio de fray Jerónimo. Sin embargo, esta libertad es relativa, ya que él sabe que deberá ceñirse a la observancia de lo establecido en la "memoria", pues su éxito depende de su cumplimiento.

Finalmente, la solicitud de que fray Jerónimo Bautista dirija la correspondencia a uno de los benefactores de la fundación, el contador don

\footnotetext{
${ }^{26}$ Obispo titular de una diócesis.

${ }^{27}$ Lo mismo sucedió con la fundación del monasterio de Huánuco: la petición se inició hacia 1650 y solo en 1716 se fundó el Beaterio Purísima Concepción de María que recién en 1914 pasó a ser convento. En el siglo XVIII, los franciscanos se negaron a asumir esa responsabilidad.

${ }^{28}$ Las órdenes religiosas que se habían establecido en el Perú hasta la fecha de la carta eran contemplativas: las franciscanas en su rama clarisas y capuchinas en 1560 en el Cuzco y en Lima en 1573; las agustinas, en 1561 en Lima; las dominicas, en Arequipa en 1590 y posteriormente en Lima en 1624; y con fecha posterior en el siglo XVII las carmelitas, en 1643 en Lima.
} 
Gonzalo de la Massa, tal vez estaba motivada por la voluntad de RSM de evitar figuración y mantener el retiro que se había impuesto.

RSM, cuando expresa sus postulados, emplea verbos en singular. Los verbos en plural "hemos de estar sujetas", "estemos sujetas al ordinario", demuestran que RSM se concebía informalmente como parte de una comunidad y como futura religiosa ${ }^{29}$ del monasterio que se proyecta. Esta idea queda más precisa en el argumento IV: "ya son cuatro las que traen el hábito, de mi madre Santa Catalina de Sena".

El esquema del argumento cuarto es: explicación [invocación] - explicación [invocación] - explicación [invocación]. Se inicia con un comentario sobre la dimensión de esta carta que escribe fray Gonzalo García a fray Jerónimo Bautista. Esa misiva debió ser clara y explicativa, pues a pesar de la importancia que RSM concede a su contenido, no menciona en su carta los puntos que se tratan en la "memoria" que se envía.

El emisor realiza dos peticiones: 1. oraciones ["me encomiende a la Divina Magestad y lo propio piden mis hermanas"] (esta petición se inscribe en el sentido de reciprocidad propia de la comunidad católica donde unos piden por los otros ["y lo propio piden mis hermanas"]); 2. traiga a Lima la imagen de Santa Catalina de Siena (era común que las imágenes vinieran de España o Europa, tal vez porque de acuerdo al concilio de Trento se buscaba la excelencia en la decoración religiosa de las iglesias ${ }^{30}$ ).

Nótese que el encargo lo realiza a un mercader, ya que se trataba de un asunto económico con el cual la persona debía estar familiarizada La elección de esa imagen se debía a que el monasterio de Santa Catalina de Siena se creaba bajo la advocación de esta Santa.

El esquema del argumento final es: explicación - invocación. Los saludos que hace presentes RSM en su carta, demuestran que fray Jerónimo Bautista era conocido por las personas más próximas a ella: doña Isabel Mejía ${ }^{31}$ y sus padres ${ }^{32}$ (consideramos que se refiere a doña María Oliva y don Gaspar Flores, sus padres

\footnotetext{
29 RSM se comportaba como una monja, María de Bustamante, monja del monasterio de la Trinidad que la conoció desde niña, ya que frecuentaba su casa, manifestó: "quanto su estado le permitía guardava los estatutos de la dicha orden [Dominica] y de Santa Catalina de Sena de la qual era muy devota" (AAL. Proceso, María de Bustamante 1630: 315). Esa Regla le llegó a través de fray Juan Miguel, a quien la Santa se la pidió; y para el efecto, él la solicitó a un religioso amigo en el Cuzco quien se la envió. Posteriormente supo que RSM la guardaba con mucha puntualidad.

${ }^{30}$ El encargo de las obras de arte religioso a Europa era frecuente sobre todo durante el primer siglo, mientras llegaban artistas a América o surgían aquí.

31 Doña Isabel Mejía Arébalo tenía amistad con la familia de RSM. Testificó en 1617, no así en 1630, posiblemente ya había fallecido entonces. En 1617 ya era viuda y tenía 60 años.

${ }^{32}$ La posible confusión proviene porque el término es ambiguo y puede referirse a diversos tipos de parentesco: consanguíneo, social, legal y adoptivo (tutores) y a un valor teológico (religioso) de la persona que guía a otra y se le considera padre.
}

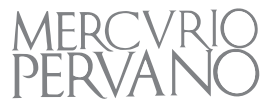


naturales y todavía no a don Gonzalo de la Massa y a doña María de Usátegui que la apoyaban y la asumieron como hija y también los llamaba padres ${ }^{33}$ ).

Un dato que en muchas cartas no se incluye es la fecha que nos remite a once años antes de la fundación del monasterio de Santa Catalina que fue en 1624. En la despedida, como se mencionó emplea una fórmula de devoción y una de sumisión. Se presenta como "esclava" de Jesús que equivale a una entrega espiritual y física a Dios y "sierva" de fray Jerónimo Bautista, esto es con obligación de obediencia.

\section{Conclusiones}

A través de la primera carta, todo el discurso se construye con el presupuesto y la confianza puesta en el logro del objetivo de la fundación del monasterio de Santa Catalina porque se concibe que de esa manera se contribuiría al desarrollo espiritual y sería semillero de vocaciones.

A pesar de los escuetos datos en la carta, hay una riqueza informativa: existe un planeamiento global de los requerimientos para la fundación del monasterio con una ejecución simultánea y seguimiento de los trámites en España y en el Perú realizados sincrónicamente; asimismo, una preparación de lo necesario para su funcionamiento con avances concretos: doncellas dispuestas a ser religiosas, la sujeción al ordinario; además, comentarios sobre la ubicación y renta del monasterio y la compra de imágenes religiosas para el culto. Todo evidencia logros y muestra el carácter ejecutivo de RSM: su decisión, voluntad férrea y emprendedora, que no decae ante las "contradicciones" (que "son muchas", como la santa misma menciona). Pese a las dificultades, a RSM la anima la certeza de que esa obra se haría realidad, como lo testimonia, entre otras personas, fray Pedro de Loayza, confesor de RSM, "sabe que la dicha bendita Rosa deseó con gran voluntad, fundar el convento de Santa Catalina de Siena y así lo procuró no solo en la corte, sino en esta ciudad de Lima, buscando personas que la quisiesen ayudar [...] tenía confianza tan firme en Dios, que lo había de ver fundado; pero no sabía el cuando". ${ }^{34}$

Sorprende que sea una mujer modesta, sin recursos económicos y alejada del mundo quien asuma esa iniciativa, sea la promotora de una obra de tal envergadura y se dirija a un religioso para instarle a obrar. Se puede destacar

\footnotetext{
${ }_{33}$ Nos inclinamos por esta opción, porque RSM conoció a don Gonzalo de la Massa y a doña María de Usátegui en 1612 y al año siguiente fue a vivir en su casa. Aunque los consideraba sus "padres espirituales", era una fecha muy reciente para llamarlos públicamente "padres" ante terceros; además, RSM tenía sumo cuidado de hacer pública su vida privada y evitaba que los demás se ocupen de su persona.

34 Hernán JimÉnez SAlAs O.P. (compilador), Primer proceso ordinario para la canonización de Santa Rosa de Lima. Lima, s.e. (Contiene la transcripción de documentos y testimonios de los testigos.), 2002 [1617-1618], p. 284.
} 
que la carta menciona la colaboración de varias personas en la fundación de monasterio. Por su parte, RSM mantiene cierta comunicación con algunas, pese a su retiro y alejamiento de las relaciones sociales. No se evidencia ningún deseo de protagonismo, al contrario, el texto refleja la fe y confianza en la providencia divina, ese es el fundamento de su fortaleza para seguir adelante, más allá de parámetros humanos, dada la naturaleza de esa fundación que es de largo aliento y trascendería la existencia de los promotores, ya que perduraría a través del tiempo porque existe actualmente. RSM asume un liderazgo, está enterada de las actividades que se realizan y de los detalles del caso y, pese a las contrariedades, sus comentarios los expresa con ponderación y prudencia.

Esa carta demuestra la importancia de la correspondencia enviada desde el Perú a España y viceversa como único medio capaz de conectar, iniciar o reiniciar un 'diálogo' entre corresponsales, pese a las múltiples dificultades, peligros, tiempo del viaje, precariedad del sistema de correos o supeditación a la buena voluntad de terceros. Premisas fundamentales para la construcción textual, en consecuencia, una virtud fundamental era que una carta sea clara, contenga la información necesaria completa y tenga una extensión adecuada. Lo contrario suscita reclamo, como se manifiesta en una carta del 24 de agosto de 1568 enviada desde el Perú por Doña Francisca Maldonado a su hijo en España: "hazme tanto placer [...] que no escribas diezyocho renglones, como me escribiste ahora" ${ }^{\prime 35}$ y desde España también se expresa lo mismo: el 15 de diciembre de 1581 santa Teresa de Jesús, en una misiva a su sobrino Lorenzo de Cepeda en Quito le dice "que escribe muy corto para estar tan lejos". ${ }^{36}$ La carta de RSM al padre Jerónimo Bautista aborda el motivo central: agilizar los trámites para lograr la autorización de la fundación del monasterio de Santa Catalina, es precisa y contiene la información necesaria.

Esa carta revela la importancia de la iniciativa particular en la ejecución de obras de trascendencia social como la fundación de conventos, en este caso, impulsada por RSM que demuestra su decisión. Estilísticamente, se enmarca en la prosa epistolar propia de la época que aplica construcciones lingüísticas directas, aunque hay alguna expresión más elaboradas dentro de una retórica propia del Barroco como "apresure el paso porque ya no es tiempo Padre mio de cernir, mas antes es ya tiempo de aMassar". La carta presenta los contenidos que se abordan con mesura, con una secuencia lógica ordenada y coherente, y precisión semántica y léxica. Está escrita a puño y letra por la propia autora, punto que destacamos por la frecuencia en esa época a dictarlas. ${ }^{37}$

\footnotetext{
35 E. OtTÉ, p. 382.

36 Teresa de Jesús, Cartas. Burgos, Editorial Monte Carmelo, 1997, p. 1087.

${ }^{37}$ Ese dato lo considero porque forma parte de una investigación que he realizado sobre cartas de mujeres en el Perú en los siglos XVI y XVII donde estudio las particularidades estilísticas de la redacción de esas misivas.
}

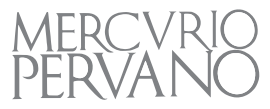


La tercera carta evidencia cómo la misiva es un medio de comunicación por excelencia dentro de las convenciones sociales en los siglos XVI y XVII en Lima, pese a ser una ciudad pequeña. El billete (carta corta) que RSM envía a doña María de Usátegui se enmarca dentro de práctica usual. Ese texto aplica uno de los códigos de cortesía: el agradecimiento por un favor recibido es signo de urbanidad y gratitud; además, revela el trato armonioso de RSM con personas cercanas, lo cual tampoco quiebra su alejamiento voluntario y poco trato con otras personas, como lo destacan las 75 personas que testimonian en el Expediente en 1617 y las 147 personas en el Proceso apostólico de 1630-1632, ${ }^{38}$ que ponderan el trato afable y buena disposición de RSM.

Aunque era costumbre en la época el intercambio epistolar en la propia ciudad, debió ser menos usual entre las mujeres por ser un sector analfabeto que acudía a secretarios para la redacción y/o lectura. Lo particular, en este caso, es que la remitente y posiblemente la receptora sabían leer y escribir, y gozaban de una formación intelectual superior al común. Otro detalle significativo es que RSM escribe esa carta en unos minutos, mientras espera el mensajero de doña María de Usátegui. Resulta significativa esa habilidad de la autora y se la puede relacionar con el propio testimonio de RSM en su texto las Mercedes en la escala mística. Allí alude explícitamente a su rapidez al producirlo, punto revelador puesto que ella pertenece a un sector escasamente cultivado y alejado de la actividad escritural. En este sentido, escapa al perfil intelectual consuetudinario atribuido a la mujer. Más aún por la densidad semántica y complejidad que entraña la producción de las Mercedes ${ }^{39}$ realizadas en una tarde o en un días, como RSM lo manifiesta: "Víspera de mi padre y apóstol san Bartolome ise las dos obras que remito en dos y medio pliegos" (ASR: 16|7). Todo ello revela la agudeza de RSM.

\footnotetext{
${ }^{38} \mathrm{El}$ dato sobre la cantidad de personas que testimonian está en el artículo de Teodoro HAMPE Martínez, "Los testigos de Santa Rosa. (Una aproximación social a la identidad criolla en el Perú colonial)". Recuperado el 5 de octubre de 2017 de file:/ / E:/ Rosa/Downloads/3007930098-1-PB.PDF

${ }^{39}$ Para detalles sobre el texto, véase Rosa CARRASCO, Santa Rosa de Lima: escritos..., pp. 38-63.
} 


\section{Referencias Bibliográficas}

Álvarez PercA, Guillermo, Santa Rosa de Lima, Una realización de la vocación cristiana. Lima, Convento de Santo Domingo, 1992.

Carrasco Ligarda, Rosa, “La comunicación verbal de Rosa de Santa María” en Consensus. Revista de la Universidad Femenina del Sagrado Corazón, Centro de Investigación, Año 5, N. 5, 2001, pp. 55-70.

-_, Santa Rosa de Lima: escritos de la santa limeña, Lima, Facultad de Teología Pontificia y Civil de Lima. Provincia Santa Rosa Perú, San Pablo 2016.

Catá de Calella, José Antonio, Vida portentosa de la esclarecida virgen santa Rosa de Santa María, vulgo Rosa de Lima. Barcelona, Tipografía Católica, 1896.

Cayetano, Bruno, Rosa de Santa María. La sin igual historia de Santa Rosa de Lima, narrada por los testigos oculares del proceso de su beatificación y canonización. Lima, Editorial Salesiana, 1992.

Chueca, Ubaldo, Santa Rosa de Lima. Lima, Editorial Salesiana, s/f.

Curtius, Ernest Robert, Literatura europea y Edad Media latina. Méjico, Fondo de Cultura Económica, 1955.

Del Busto Duthurburu, José Antonio, Santa Rosa de Lima (Isabel Flores de Oliva). Lima, Pontificia Universidad Católica del Perú, 2006.

Getino, Luis Alonso, La patrona de las Américas. Santa Rosa de Lima Doctora. Su personalidad intelectual. Lima, Talleres gráficos de la Penitenciaría, 1920.

-_, Santa Rosa de Lima, patrona de América, Su retrato corporal y su talla intelectual según los nuevos documentos. Aguilar, Madrid, 1943.

Hampe Martínez, Teodoro, “Los testigos de Santa Rosa. (Una aproximación social a la identidad criolla en el Perú colonial)". Recuperado el 5 de octubre de 2017 de file:///E:/Rosa/Downloads/30079-30098-1-PB.PDF

HANSEN, Leonardo, Vida de la bienaventurada Rosa de Santa María de la tercera Orden de Santo Domingo. Natural del Reyno del Perú. Madrid, Melchor Sánchez, 1668 [1664].

JimÉnez SAlas, Hernán (compilador). Primer proceso ordinario para la canonización de Santa Rosa de Lima. Lima [1617-1618], s.e, 2001.

LA RosA, Lino, "Santa Rosa y su inspiración" en Santa Rosa de Lima en la cumbre del San Cristóbal, Imprenta del Ministerio de Guerra, Lima, 1981, pp. 120-125.

LAUSBERG, Henrich, Elementos de retórica literaria. Madrid, Gredos. Versión española de Mariano Marín Casero, Biblioteca Románica española, dirigida por Dámaso Alonso, Manuales, 1975, pp. 36-261. 
Le Guern, Michel, La metáfora y la metonimia. Madrid, Cátedra, 1973.

Longino, De lo sublime. Buenos Aires, Aguilar, 1972.

López Amat, Alfredo, Mary Ward: el drama de una pionera. Madrid, Biblioteca de Autores Cristianos, 1990.

Montara Garavelli, Bice, Manual de retórica. Madrid, Cátedra, 1991.

Mujica Pinilla, Ramón, “El ancla de santa Rosa de Lima: Mística y política en torno a la patrona de América" en Santa Rosa de Lima y su tiempo, Lima, Ausonia, 1995, pp. 54-211.

Osende, Victorino, Santa Rosa de Lima, Lima, Talleres de Artes Gráficas de Ramírez Hermanos, 1914.

Отте́, Enrique, Cartas privadas de inmigrantes a Indias, Sevilla, V Centenario Consejería de Cultura Justa de Andalucía. Escuela de Estudios Hispanoamericanos, Gráfica del Exportador, 1988.

PRINCE, Carlos, Vida edificante de la gloriosa Santa Rosa de Lima Patrona universal de América, Filipinas e Indias, Lima, Carlos Prince impresor y editorlibrero, 1886.

Rodríguez Crespo, Pedro, "Santa Rosa de Lima”, en Hombres del Perú, Lima, Tipografía peruana, 1964, pp. 5-58.

TeResA De Jesús. Vida en Obras completas. Burgos, Editorial Monte Carmelo. Texto revisado y anotado por Fray Tomás de la Cruz CD, 1984 [1588], pp. 2-499.

__, Cartas. Burgos, Editorial Monte Carmelo, 1997.

\section{Manuscritos}

\section{Archivo Arzobispal de Lima (AAL)}

Proceso Apostólico de beatificación de Rosa de Santa María que se levantó en Lima, Gerónimo Bautista. 1630-1632.

Monasterio de la Encarnación: Micaela Iporri, leg. 1, p. 6, s. XVII.

Monasterio de la Encarnación Jacoba de Larrinaga Salazar III:39 s/n. 1631.

Monasterio del Carmen: Ana de San Joseph, III: 39.

Monasterio Descalzas de San José: Beatriz de la Ascención, 1.2, s/n. 1637.

Id. Arcangela Micaela, III:11. 1679.

Id. Leg. I, exp. 1, s/n. 1669

Expediente Ordinario de beatificación de Rosa de Santa María. 1617-1618.

Monasterio de Santa Rosa. (MSR)

Carta de santa Rosa a doña María de Usátegui. 1614?

Carta al padre Bartolomé Ayala. 1613? 